\title{
Adakah Pengaruh Event dalam Economic Calendar terhadap Gold Price (XAU/USD)?
}

\author{
Emilda $^{1)}$ \\ 1) Program Studi Manajemen, Universitas Indo Global Mandiri \\ Jl. Jend. Sudirman No. 629, Palembang, 30129 \\ Email:emilda@uigm.ac.id ${ }^{1)}$
}

\begin{abstract}
This research is based on phenomena that exist in the world of traders who make events in the economic calendar as one of the fundamental analysis references in making trading decisions. Event data released in the economic calendar are expected to have an impact on the market. This study aims to determine whether there is an influence of the event released in the economic calendar on the gold price (XAU/USD). Data analysis techniques in this study using SPSS, namely IBM Statistics SPSS 24. Data analysis methods in this study are the dependent methods. This study uses monthly event data and the monthly gold price (XAU/USD) for 3 years, namely the period 2017 to 2019 . The gold price in this study is the change in the price of spot dollar gold futures (XAU/USD), while the event in this study are events that are estimated to have a high and moderate impact on the price of gold futures (XAU/USD). From five hypotheses in this study, there were three hypotheses that were accepted and two hypotheses that were not accepted. The results in this study, the Federal Funds Rate variable has a positive influence on the price of gold (XAU/USD), the ISM Manufacturing PMI variable, the Unemployment Rate, ADP non - farm employment have negative influence on the price of gold (XAU/USD). Whereas, Average Hourly Earning does not have a significant effect on the price of gold (XAU/USD).
\end{abstract}

Keywords: Event, Economic Calendar, and Gold Price (XAU/USD)

\begin{abstract}
ABSTRAK
Penelitian ini didasarkan pada fenomena yang ada di dunia pedagang yang membuat peristiwa dalam kalender ekonomi sebagai salah satu referensi analisis fundamental dalam pengambilan keputusan perdagangan. Data acara yang dirilis dalam kalender ekonomi diharapkan berdampak pada pasar. Penelitian ini bertujuan untuk mengetahui apakah ada pengaruh peristiwa yang dirilis dalam kalender ekonomi terhadap harga emas (XAU/USD). Teknik analisis data dalam penelitian ini menggunakan SPSS, yaitu IBM Statistics SPSS 24. Metode analisis data dalam penelitian ini adalah metode dependen. Penelitian ini menggunakan data peristiwa bulanan dan harga emas bulanan (XAU/USD) selama 3 tahun, yaitu periode 2017 hingga 2019. Harga emas dalam penelitian ini adalah perubahan harga emas berjangka spot dolar (XAU/USD), sedangkan event dalam penelitian ini adalah event yang diperkirakan memiliki dampak tinggi dan sedang pada harga emas berjangka (XAU/USD). Dari lima hipotesis dalam penelitian ini, ada tiga hipotesis yang diterima dan dua hipotesis yang tidak diterima. Hasil dalam penelitian ini, variabel Federal Funds Rate memiliki pengaruh positif pada harga emas (XAU/USD), variabel PMI Manufaktur ISM, Unemployment Rate, ADP non-farm employment memiliki pengaruh negatif pada harga emas (XAU/USD). Sedangkan, Penghasilan Per Jam Rata-rata tidak memiliki pengaruh signifikan terhadap harga emas (XAU/USD).
\end{abstract}

Kata Kunci: Peristiwa, Kalender Ekonomi, Harga Emas

\section{Pendahuluan}

Ada dua jenis Bursa di Indonesia yaitu Bursa Efek Indonesia (BEI) dan Bursa Berjangka Jakarta (BBJ). Menurut UU No. 8 Tahun 1995, BEI adalah Bursa yang menyelenggarakan penawaran jual dan beli Efek. Sedangkan BBJ menurut UU No 10 tahun 2011 tentang perdagangan berjangka komoditi, Bursa berjangka adalah bursa yang menyelenggarakan kegiatan jual beli komoditi berdasarkan Kontrak Berjangka.Pada umumnya, produk berjangka yang ditawarkan oleh perusahaan pialang berjangka yaitu forex, index saham, dan emas berjangka spot dollar (XAU/USD).

Dalam mengambil keputusan investasi, ada dua jenis analisis investasi yang digunakan oleh seorang trader dan investor yaitu analisis fundamental dan tekhnikal.
Menurut Husnan (2009), analisis fundamental melakukan penilaian dalam beberapa hal, salah satunya penilaian terhadap kondisi ekonomi. Sedangkan, analisis tekhnikal pada dasarnya merupakan analisis yang menggunakan analisis grafis atau memanfaatkan indikator - indikator teknis dalam upaya untuk menentukan kapan akan masuk atau keluar pasar.

Dalam analisis tekhnikal, trader dan investor menggunakan data historis masa lalu untuk memprediksi pergerakan harga. Pada analisis fundamental tergantung jenis investasi yang dipilih, jika investasi pada sekuritas yang diperdagangkan di Bursa Efek Indonesia (BEI), selain mengamati kondisi pasar, juga perlu melakukan penilaian terhadap industri dan perusahaan. Lain halnya, jika berinvestasi pada produk berjangka di Bursa 
Berjangka Jakarta (BBJ). Pada umumnya, seorang trader menjadikan event dalam economic calandar berupa indikator ekonomi dan keputusan kebijakan moneter dimana pengumuman jadwal event dalam economic calendar biasanya diinformasikan di website perusahaan pialang berjangka sebagai referensi dalam mengambil keputusan trading.

Selain itu, economic calendar tidak hanya menginformasikan event berupa indikator ekonomi dan keputusan kebijakan moneter dunia. Tetapi juga, memberikan infomasi mengenai perkiraan tingkat dampak yang terdiri dari low, moderate, dan high impact dari setiap event yang rilis. Menurut Trijuni (2020) dalam website https://www.foreximf.com, ada 3 jenis pemberitaan yang memberikan pengaruh terhadap pasar yaitu pemberitaan tentang politik, pengumuman suku bunga, dan data ekonomi dunia yang rilis.

Menurut Zhou, Y., Han, L., \& Yin, L (2018) ketidakpastian ekonomi memberikan dampak langsung pada korelasi antara emas dan dolar. Selain itu, ketidakpastian yang bersumber dari ekonomi yang berbeda memiliki dampak yang berbeda pada emas dan dolar. Sebagian besar hasil penelitian mengemukakan bahwa harga emas sangat dipengaruhi oleh mata uang dollar, harga emas memiliki hubungan yang berlawanan terhadap dollar yang artinya jika kurs dollar naik, maka harga emas akan turun dan sebaliknya.

Penelitian ini memfokuskan pada salah satu produk berjangka yang sering ditawarkan oleh perusahaan pialang berjangka di Bursa Berjangka Jakarta (BBJ) yaitu emas berjangka spot dollar (XAU/USD) dan hanya mengambil event dalam economic calendar diperkirakan memiliki high dan moderate impact terhadap pasar. Penelitian ini bertujuan untuk membuktikan apakah event yang terdapat dalam economic calendar yang diprediksi memiliki high dan moderate impact berpengaruh secara signifikan terhadap harga produk berjangka di BBJ khususnya harga emas berjangka spot dollar (XAU/USD)

\section{Landasan Teori}

\subsection{Bursa Berjangka}

Menurut UU No 10 tahun 2011 Bursa Berjangka adalah badan yang menyelenggarakan dan menyediakan sarana dalam aktivitas jual beli komoditi berdasarkan Kontrak Berjangka, Kontrak Derivatif Syariah, dan/atau Kontrak Derivatif lainnya. Kontrak Berjangka adalah kontrak untuk membeli atau menjual komoditi dengan penyelesaian sebagaimana ditetapkan yang terdapat dalam kontrak yang diperdagangkan di Bursa Berjangka. Kontrak Derivatif adalah kontrak yang nilai dan harganya bergantung pada subjek komoditi.

Menurut Permen RI No.49 Tahun 2014, Bursa Berjangka didirikan minimal 11 (sebelas) badan usaha yang berbentuk perseroan terbatas yang satu dengan lainnya tidak terafiliasi. setelah memperoleh izin usaha dari Kepala Bappebti, Bursa Berjangka baru bisa melakukan kegiatannya Modal disetor Bursa Berjangka minimal berjumlah Rp100.000.000.000,00 (seratus miliar rupiah).
Badan Pengawas Perdagangan Berjangka Komoditi yang selanjutnya disebut Bappebti adalah lembaga yang tugas pokoknya melakukan pembinaan, pengaturan, pengembangan, dan pengawasan Perdagangan Berjangka.

\subsection{Perusahaan Pialang Berjangka}

Menurut UU No 10 tahun 2011, Pialang Perdagangan Berjangka atau Pialang Berjangka adalah badan usaha yang melakukan kegiatan jual beli komoditi berdasarkan Kontrak Berjangka, Kontrak Derivatif Syariah, dan/atau Kontrak Derivatif lainnya atas amanat Nasabah dengan menarik sejumlah uang dan/atau surat berharga tertentu sebagai margin untuk menjamin transaksi tersebut.

Margin adalah sejumlah uang atau surat berharga yang harus ditempatkan oleh Nasabah pada Pialang Berjangka, Pialang Berjangka pada Anggota Kliring Berjangka, atau Anggota Kliring Berjangka pada Lembaga Kliring Berjangka untuk menjamin pelaksanaan transaksi Kontrak Berjangka, Kontrak Derivatif Syariah, dan/atau Kontrak Derivatif lainnya.

Pada umumnya, produk yang dipasarkan oleh perusahaan pialang berjangka kepada masyarakat terdiri dari forex, index saham, dan emas berjangka spot dollar (XAU/USD). Index saham misalnya Indeks Saham Hongkong dan Indeks Saham Jepang. Indeks Saham Hongkong merupakan produk derivatif dari indeks hangseng yang ditransaksikan melalui mekanisme sistem perdagangan alternative di Bursa Berjangka Jakarta dengan harga referensi mengacu kepada Hangseng Index Futures dan Nikkei 225 Index Futures. Foreign Exchange (Valuta Asing) yang diperdagangkan yaitu Pound Sterling, Euro, Australian Dollar, Swiss Franc, Yen pada harga spot US Dollar (USD). Emas yang diperdagangkan adalah emas berjangka spot dollar (XAU/USD) yang ditransaksikan melalui sistem perdagangan alternatif di Bursa Berjangka Jakarta.

\subsection{Economic Calendar}

Jadwal event dalam economic calendar biasanya diinformasikan di website perusahaan pialang berjangka sebagai referensi dalam mengambil keputusan trading. Indikator ekonomi biasanya dirilis oleh badan pemerintah, organisasi, dan lembaga riset yang memberikan informasi tentang kondisi, aktivitas ekonomi, maupun pengumuman keputusan kebijakan moneter dari berbagai negara.

Potensi dampak dari setiap event juga ditampilkan dalam economic calendar berupa penanda tingkat volatilitas atau besarnya pergerakan pasar yang diperkirakan dipicu oleh setiap event tersebut. Ada tiga macam penanda atau simbol dari perkiraan potensi pergerakan pasar yang dipicu dari setiap event yang terdapat dalam economic calendar. pertama, potensi pergerakan pasar rendah yang disimbolkan dengan satu banteng. Kedua, potensi pergerakan pasar menengah yang disimbolkan dengan dua banteng. Ketiga, potensi pergerakan pasar tinggi yang disimbolkan dengan tiga banteng. 
Berdasarkan informasi yang diperoleh dari website perusahaan pialang dan keuangan yaitu http://www.rfinancindoberjangka.com/ dan https://id.investing.com, berikut beberapa indikator ekonomi yang diperkirakan memiliki potensi high dan moderate impact terhadap pasar, diantaranya:
1. Federal Fund Rate
2. Unemployment rate
3. Average Hourly Earnings Non - Farm Employment
4. ADP Non-Farm Employment
5. ISM Manufacturing PMI

\subsection{Emas Berjangka Spot Dollar (XAU/USD)}

Ada tiga jenis investasi emas yaitu investasi emas dalam bentuk fisik, investasi emas dalam bentuk perhiasan, investasi emas dalam satuan trading. Menurut Suharto (2013), emas merupakan salah satu yang paling stabil dan efektif. Selain itu juga emas sering disebut sebagai pengukur modal dan dimensi kekayaan yang paling tua dan efektif.

Emas berjangka spot dollar (XAU/USD) merupakan salah satu produk yang sering ditawarkan oleh perusahaan pialang berjangka. Sebagaimana yang kita tahu, emas disebut sebagai safe haven karena nilai emas bisa stabil atau bahkan bisa meningkatkan walaupun pasar sedang tidak stabil sehingga investasi emas dijadikan salah satu investasi yang dianggap aman oleh investor untuk menghindari asset dari kerugian yang diakibatkan kondisi pasar yang tidak stabil.

\subsection{Hubungan Event dalam Economic Calendar terhadap Gold Price (XAU/USD)}

Penelitian tentang Gold Price dengan berbagai variabel penelitian yang berbeda sudah banyak dilakukan, diantaranya Smith (2001), Ghosh et al. (2002), Sjaastad (2008), Öztürk and Açıkalın (2008), dan lain - lain. Smith (2001) melakukan penelitian hubungan antara harga emas dan harga saham, Ghosh et al. (2002) tentang pengaruh tingkat inflasi, pendapatan, nilai Dolar AS terhadap harga emas, Sjaastad (2008) tentang hubungan harga emas dan nilai tukar, Öztürk dan Açıkalın (2008) tentang hubungan antara harga emas dan consumer price index.

Namun, masih sangat jarang yang melakukan penelitian pada event yang rilis yang terdapat dalam economic calendar terhadap gold price (XAU/USD) padahal pada prakteknya, event yang rilis yang terdapat dalam economic calendar pada umumnya dijadikan oleh trader sebagai salah satu referensi dalam mengambil keputusan investasi atau trading.

Menurut Trijuni (2020) dalam website https://www.foreximf.com, ada 3 jenis pemberitaan yang memberikan pengaruh terhadap pasar yaitu pemberitaan tentang politik, pengumuman suku bunga, dan data ekonomi dunia yang rilis. Kondisi politik yang tidak stabil akan berpengaruh terhadap mata uang suatu negara. Tingkat suku bunga juga berpengaruh terhadap nilai mata uang suatu negara karena tingkat suku bunga memiliki hubungan yang positif terhadap mata uang, ketika tingkat suku bunga naik, maka nilai mata uang juga akan meingkat, dan sebaliknya. Dan yang terakhir, hal yang perlu diperhatikan oleh trader adalah data ekonomi negara. Ada beberapa event dalam economic calendar yang memicu pergerakan harga yang signifikan dalam beberapa menit setelah rilis.

Menurut Zhou, Y., Han, L., \& Yin, L (2018) ketidakpastian ekonomi memberikan dampak langsung pada korelasi antara emas dan dolar. Selain itu, ketidakpastian yang bersumber dari ekonomi yang berbeda memiliki dampak yang berbeda pada emas dan dolar. Hal ini juga didukung oleh hasil penelitian sebelumnya yang dilakukan oleh Fergal O'Connor (2012) dan Toraman, Cengiz \& Başarır, Çağatay \& Bayramoglu, M.F. (2011) yang menyatakan bahwa nilai kurs dolar berpengaruh terhadap harga emas dan memiliki hubungan yang negatif terhadap harga emas.

Economic Calendar memuat tentang indikator ekonomi dunia yang akan rilis yang dapat mempengaruhi pasar khususnya untuk mata uang. Berikut tabel hubungan event yang terdapat dalam economic calendar yang diperkirakan memiliki potensi high and moderate impact terhadap mata uang dimana gold price (XAU/USD) memiliki hubungan yang negatif terhadap mata uang.

Tabel 1. Hubungan Event dalam Economic Calendar dengan Mata Uang dan Gold Price (XAU/USD)

\begin{tabular}{|c|c|c|c|}
\hline \multirow{2}{*}{ Data Ekonomi } & \multirow{2}{*}{ Aktual vs Perkiran } & \multicolumn{2}{|r|}{ Usual Effect } \\
\hline & & Forex & Gold Price (XAU/USD) \\
\hline Federal Fund Rate & Aktual > Perkiraan & - & + \\
\hline Unemployment Rate & Aktual > Perkiraan & - & + \\
\hline $\begin{array}{l}\text { Average Hourly Earnings } \\
\text { Non-Farm Employment }\end{array}$ & Aktual > Perkiraan & + & - \\
\hline $\begin{array}{l}\text { ADP Non-Farm } \\
\text { Employment }\end{array}$ & Aktual > Perkiraan & + & - \\
\hline ISM Manufacturing PMI & Aktual > Perkiraan & + & - \\
\hline Sumber: & tp: //www.rfinc & ncina & oberjangka.com \\
\hline
\end{tabular}

Federal Fund Rate merupakan tingkat bunga dimana bank meminjamkan saldo yang disimpan Federal Reserve untuk bank lain. Jika nilai aktual Federal Fund Rate lebih besar dari yang diharapkan akan berdampak negatif untuk USD dalam jangka pendek, tetapi berdampak positif dalam jangka panjang untuk menanggulangi inflasi.

Unemployment Rate merupakan Tingkat pengangguran yang diukur dari persentase total angkatan kerja yang menganggur dan secara aktif mencari pekerjaan selama bulan sebelumnya. Nilai aktual unemployment rate yang lebih tinggi dari yang diharapkan berdampak negatif untuk USD dan jika nilai aktual Unemployment Rate lebih rendah dari yang diharapkan akan berdampak positif untuk USD

Average Hourly Earnings Non-Farm Employment merupakan penghasilan per jam rata - rata mengukur perubahan harga yang dibayar untuk tenaga kerja, selain sektor pertanian. Jika nilai aktual Average Hourly Earnings Non - Farm Employment lebih tinggi dari yang diharapkan, maka akan berdampak positif untuk USD dan sebaliknya, jika nilai aktual Average Hourly Earnings Non - Farm Employment yang lebih rendah dari yang diharapkan, maka akan berdampak negatif untuk USD.

ADP Non-Farm Employment merupakan laporan ketenagakerjaan non-pertanian berdasarkan data 
penggajian sekitar 400.000 klien bisnis A.S. Rilis dua hari lebih cepat dari data pemerintah berarti prediktor yang baik untuk laporan pendapatan non-pertanian. Perubahan indikator ini bisa sangat fluktuatif. Nilai aktual ADP NonFarm Employment yang lebih tinggi dari yang diharapkan akan berdampak posisi untuk USD dan Nilai aktual $A D P$ Non-Farm Employment yang lebih rendah dari yang diharapkan akan berdampak negatif untuk USD.

Institute of Supply Management (ISM) Manufacturing Purchasing Managers Index, laporan bisnis didasarkan pada data tentang pembelian dan penyediaan di lebih dari 400 perusahaan industri. Untuk setiap indikator yang diukur (Pesanan Baru, Tumpukan Pesanan, Pesanan Ekspor Baru, Impor, Produksi, Pengiriman Pemasok, Persediaan, Persediaan Pelanggan, Ketenagakerjaan, dan Harga. Nilai aktual PMI lebih tinggi dari yang diharapkan merupakan sinyal positif untuk USD dan nilai aktual PMI yang lebih rendah dari yang diharapkan merupakan sinyal negatif untuk USD.

\subsection{Hipotesis}

Dari latar belakang dan landasan teori diatas, maka rumusan hipotesis dalam penelitian ini sebagai berikut

H1: Federal Fund Rate memiliki pengaruh positif terhadap gold price (XAU/USD)

$\mathrm{H} 2$ : Unemployment Rate memiliki pengaruh positif terhadap gold price (XAU/USD)

H3: Average Hourly Earnings Non - Farm Employment memiliki pengaruh negatif terhadap gold price (XAU/USD)

H4: ADP Non - Farm Employment memiliki pengaruh negatif terhadap gold price (XAU/USD)

H5: ISM Manufacturing PMI memiliki pengaruh negatif terhadap gold price (XAU/USD)

\section{Metode Penelitian}

Metode statistik dalam penelitian ini adalah regresi sederhana karena variabel bebas tidak diuji secara bersama - sama terhadap variabel terikat. Menurut Ghozali (2016), regresi adalah metode statistik untuk menguji hubungan antara satu variabel terikat dan satu atau lebih variabel bebas. Regresi sederhana (simple regression) untuk menguji pengaruh satu variabel bebas terhadap satu variabel terikat. Teknik analisis data dalam dalam penelitian ini menggunakan SPSS yaitu IBM Statistics SPSS 24.

\subsection{Pengumpulan Data}

Jenis data dalam penelitian ini adalah data sekunder. Penelitian ini menggunakan data event yang terdapat di economic calendar dan gold price (XAU/USD) bulanan selama 3 tahun yaitu periode 2017 hingga 2019. Sumber data Gold Price (XAU/USD) diperoleh dari https://id.investing.com/ dan event yang terdapat dalam economic calendar dari http://www.rfinancindoberjangka.com/.

Gold price dalam penelitian ini adalah harga emas berjangka spot dollar (XAU/USD), sedangkan event yang terdapat dalam economic calendar pada penelitian ini adalah event yang diprediksi memiliki high dan moderate impact terhadap pasar. Harga emas berjangka yang diambil berdasarkan harga emas sesuai tanggal rilis dari data ekonomi yang terdapat di economic calendar. Berikut jadwal rilis dari event yang terdapat di economic calendar.

Tabel 2. Frekuensi Rilis Event dalam Economic Calendar

\begin{tabular}{|l|l|}
\hline Data Ekonomi & Frekuensi \\
\hline Federal Fund Rate & Jadwal rilis 8x setahun \\
\hline Unemployment Rate & $\begin{array}{l}\text { Rilis bulanan, biasanya di jumat pertama setelah } \\
\text { bulan berjalan }\end{array}$ \\
\hline $\begin{array}{l}\text { Average Hourly Earnings Non- } \\
\text { Farm Employment }\end{array}$ & $\begin{array}{l}\text { Rilis bulanan, biasanya di jumat pertama setelah } \\
\text { bulan berjalan }\end{array}$ \\
\hline ADP Non-Farm Employment & Rilis bulanan, sekitar 2 hari setelah bulan berjalan \\
\hline ISM Manufacturing PMI & $\begin{array}{l}\text { Rilis bulanan, biasanya hari kerja pertama setelah } \\
\text { periode berjalan }\end{array}$ \\
\hline Sumber. & http
\end{tabular}
https://id.investing.com

\subsection{Variabel penelitian}

Variabel dalam penelitian ini adalah event yang terdapat dalam economic calendar dan Gold Price (XAU/USD). Variabel independen dalam penelitian ini adalah event dari negara AS yang terdapat dalam economic calendar yang diperkirakan memiliki high dan moderate impact terhadap pasar khususnya pada nilai mata uang dollar yang pada akhirnya mempengaruhi harga emas berjangka spot dollar (XAU/USD) yaitu Federal Fund Rate (X1), Unemployment Rate (X2), Average Hourly Earnings Non - Farm Employment (X3), ADP Non - Farm Employment (X4), ISM Manufacturing $P M I(X 5)$. Variabel dependen dalam penelitian ini adalah $\Delta$ gold price (XAU/USD). Harga emas berjangka spot dollar (XAU/USD) yang diambil dalam penelitian adalah perubahan harga emas berjangka spot dollar (XAU/USD) pada event rilis yang bisa dilihat dari economic calendar dimana event dalam economic calendar memiliki tanggal rilis yang berbeda-beda. Berikut tabel definisi variabel dalam penelitian ini

Tabel 3. Definisi Variabel Penelitian

\begin{tabular}{|l|l|}
\hline Variabel penelitian & \multicolumn{1}{c|}{ Definisi } \\
\hline$\Delta$ gold price & persentase perubahan harga emas (XAU/USD) \\
\hline Federal Fund Rate & $\begin{array}{l}\text { tingkat bunga dimana bank meminjamkan saldo yang } \\
\text { disimpan Federal Reserve untuk bank lain }\end{array}$ \\
\hline Unemployment Rate & $\begin{array}{l}\text { Tingkat pengangguran yang diukur dari persentase } \\
\text { total angkatan kerja yang menganggur dan secara } \\
\text { aktif mencari pekerjaan selama bulan sebelumnya }\end{array}$ \\
\hline Average Hourly Earnings & $\begin{array}{l}\text { penghasilan per jam rata - rata untuk tenaga kerja } \\
\text { selain sektor pertanian. }\end{array}$ \\
\hline ADP Non-Farm Employment & $\begin{array}{l}\text { laporan ketenagakerjaan non-pertanian berdasarkan } \\
\text { data penggajian sekitar 400.000 klien bisnis A.S }\end{array}$ \\
\hline ISM Manufacturing PMI & $\begin{array}{l}\text { Data tentang pembelian lebih dari 400 perusahaan } \\
\text { industri. }\end{array}$ \\
Sumber: \\
https://id.investing.com
\end{tabular}

\section{Pembahasan}

Untuk mengetahui apakah ada pengaruh dari event dalam economic calendar terhadap gold price (XAU/USD), penelitian ini menggunakan uji signifikansi parameter individual (uji statistik t). Dalam uji statistik t, masing - masing variabel bebas (data event dalam economic calendar) diujikan secara sendiri - sendiri terhadap variabel terikat (gold price) dikarenakan tanggal pengumuman dari setiap event dalam economic calendar yang berbeda - beda. Berikut tabel hasil uji statistik t dari masing - masing event terhadap harga emas (XAU/USD) 
Tabel 4. Hasil Uji Statistik t dari FF Rate terhadap Gold Price (XAU/USD)

Coefficients $^{\mathrm{a}}$

\begin{tabular}{|c|c|c|c|c|c|c|}
\hline \multirow[b]{2}{*}{ Model } & & \multicolumn{2}{|c|}{ Unstandardized Coefficients } & \multirow{2}{*}{$\begin{array}{c}\text { Standardized } \\
\text { Coefficients } \\
\text { Beta }\end{array}$} & \multirow[b]{2}{*}{$t$} & \multirow[b]{2}{*}{ Sig. } \\
\hline & & B & Std. Error & & & \\
\hline \multirow[t]{2}{*}{1} & (Constant) & 1215.069 & 24.154 & & 50.305 & .000 \\
\hline & FF Rate & 5980.543 & 1813.478 & .423 & 3.298 & .002 \\
\hline
\end{tabular}

a. Dependent Variable: Gold Price

Dari tabel diatas, kita dapat melihat probalitas signifikansi sebesar 0.02 yang lebih rendah dari 0.05 dan memiliki koefisien regresi yang positif. Hal ini menunjukkan hipotesis pertama diterima. Variabel Federal Fund Rate memiliki pengaruh secara positif terhadap gold price (XAU/USD), semakin tinggi nilai aktual Federal Fund Rate dibandingkan nilai yang diharapkan, maka gold price (XAU/USD) akan semakin naik. Sedangkan untuk mengetahui pengaruh variabel Unemployment Rate terhadap gold price (XAU/USD) dapat dilihat dari tabel hasil uji statistik t di bawah ini:

Tabel 5. Hasil Uji Statistik $t$ dari Unemployment Rate terhadap Gold Price (XAU/USD)

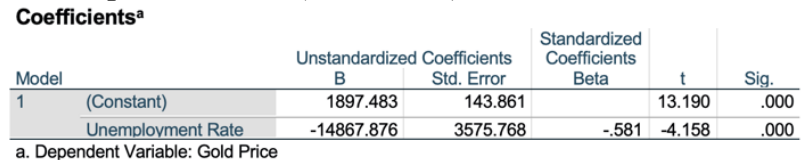

Dari tabel uji statistik $\mathrm{t}$ diatas, kita dapat melihat probabilitas signifikansi untuk Unemployment Rate terhadap gold price (XAU/USD) yaitu sebesar 0.00 yang lebih rendah dari 0.05 dan memiliki koefisien regresi yang negatif, hal ini menunjukkan hipotesis kedua tidak diterima. Variabel Unemployment Rate memiliki pengaruh secara negatif terhadap gold price (XAU/USD, semakin tinggi nilai aktual Unemployment Rate dibandingkan nilai yang diharapkan, maka gold price (XAU/USD) akan semakin turun. Sedangkan untuk mengetahui pengaruh variabel Average Hourly Earnings terhadap gold price (XAU/USD) dapat dilihat dari tabel hasil uji statistik t di bawah ini:

Tabel 6. Hasil Uji Statistik $t$ dari Average Hourly Earnings terhadap Gold Price (XAU/USD)

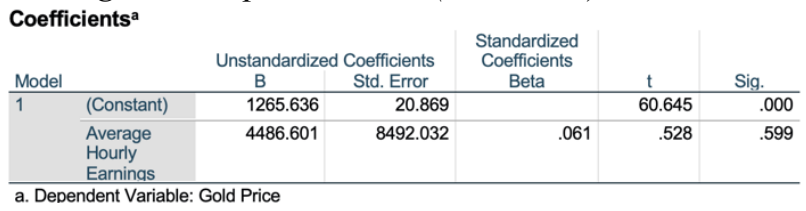

Dari tabel uji statistik t diatas, kita dapat melihat probabilitas signifikansi antara variabel Average Hourly Earnings terhadap gold price (XAU/USD) sebesar 0.599 yang lebih tinggi dari 0.05 , hal ini menunjukkan hipotesis ketiga tidak diterima. Variabel Average Hourly Earnings tidak memiliki pengaruh terhadap gold price (XAU/USD. Sedangkan untuk mengetahui pengaruh variabel ADP non - Farm Employment terhadap gold price (XAU/USD) dapat dilihat dari tabel hasil uji statistik t di bawah ini:
Tabel 7. Hasil Uji Statistik $t$ dari ADP Non-Farm Employment terhadap Gold Price (XAU/USD)

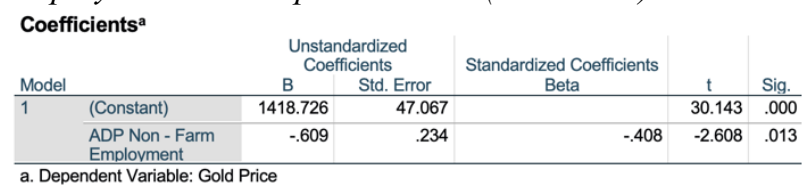

Dari tabel uji statistik t diatas, kita dapat melihat probabilitas signifikansi untuk variabel ADP non - farm employment terhadap gold price (XAU/USD) sebesar 0.013 yang lebih rendah dari 0.05 dan memiliki koefisien yang negatif. Hal ini menunjukkan hipotesis keempat diterima. Variabel ADP non-farm employment memiliki pengaruh secara negatif terhadap gold price (XAU/USD), semakin tinggi nilai aktual ADP non - farm employment dibandingkan nilai yang diharapkan, maka gold price (XAU/USD) akan semakin turun.

Tabel 8. Hasil Uji Statistikt dari ISM Manufacturing PMI terhadap Gold Price (XAU/USD)

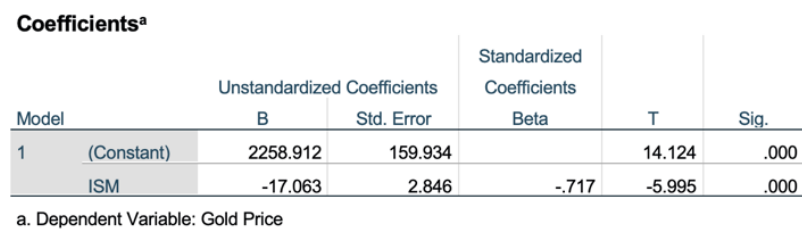

Dari tabel uji statistik t diatas, kita dapat melihat probabilitas signifikansi untuk variabel ISM Manufacturing PMI terhadap gold price (XAU/USD) sebesar 0.00 yang lebih rendah dari 0.05 dan memiliki hubungan yang negatif. Hal ini menunjukkan hipotesis kelima diterima. variabel ISM Manufacturing PMI memiliki pengaruh negatif terhadap gold price (XAU/USD), semakin tinggi nilai aktual ISM Manufacturing PMI dibandingkan nilai yang diharapkan, maka gold price (XAU/USD) akan semakin turun.

\section{Kesimpulan}

Dari lima hipotesis dalam penelitian ini, terdapat tiga hipotesis yang diterima dan sisanya tidak diterima. Hasil dalam penelitian ini, variabel Federal Fund Rate memiliki pengaruh secara positif terhadap gold price (XAU/USD), variabel ISM Manufacturing PMI, Unemployment Rate, ADP non - farm employment memiliki pengaruh negatif terhadap gold price (XAU/USD). Sedangkan Average Hourly Earnings tidak memiliki pengaruh secara signifikan terhadap gold price (XAU/USD). Penelitian bertujuan untuk mengetahui apakah ada pengaruh event yang terdapat di economic calendar terhadap perubahan gold price (XAU/USD) pada saat event rilis pada hari tersebut, sehingga dapat disimpulkan bahwa untuk jangka pendek, beberapa event yang terdapat dalam economic calendar memiliki pengaruh terhadap gold price (XAU/USD) atau dengan kata lain pasar langsung bereaksi ketika beberapa event rilis yang terdapat di economic calendar. 


\section{Daftar Pustaka}

Ghosh, D., Levin, E.J., Macmillan, P. and Wright, R.E. (2002). Gold As An Inflation Hedge?, University of St. Andrews, Department of Economics, Discussion Paper Series.

Ghozali, Imam. 2016. Aplikasi Analisis Multivariete dengan program IBM SPSS 23. Semarang: Badan Penerbit Universitas Diponegoro.

Husnan, Suad. 2009. Dasar - Dasar Teori Portofolio \& Analisis Sekuritas. Yogyakarta: UPP STIM YKPN

https://www.investing.com/ diakses tanggal 15 januari 2020.

http://www.rfinancindoberjangka.com/ diakses tanggal 02 januari 2020.

Kaewkheaw M., Leeahtam P., Chaiboosri C. (2014) An Analysis of Relationship between Gold Price and U.S. Dollar Index by Using Bivariate Extreme Value Copulas. Advances in Intelligent Systems and Computing, vol 251.

Öztürk, F. ve Açıkalın, S. (2008). Is Gold A Hedge Against Turkish Lira?, South East European Journal of Economics and Business, 3, 35-40.

Republik Indonesia. 2014. Peraturan Pemerintah No. 49 Tahun 2014 tentang Penyelenggaraan Perdagangan Berjangka Komoditi.

Republik Indonesia. 2011. Undang-Undang Republik Indonesia Nomor 10 Tahun 2011 tentang Perdagangan Berjangka Komoditi.

Republik Indonesia. 1995. Undang-Undang Republik Indonesia Nomor 8 Tahun 1995 tentang Pasar Modal.

Sjaastad, L.A. (2008). The Price of Gold and the Exchange Rates: Once Again. Elsevier, Vol 33 , Pages 118-124.

Smith, G. (2001). The Price of Gold and Stock Price Indices for the United States. Adrienne Roberts FT Personal Finance, p 14.

Suharto TF. 2013. Harga Emas Naik atau Turun Kita Tetap Untung. Jakarta (ID): Elex Media Komputindo.

Toraman, Cengiz \& Başarır, Çağatay \& Bayramoglu, M.F.. (2011). Determination of Factors affecting the Price of Gold: A Study of MGARCH Mode. Business and Economics Research Journal. 2. 37-50.

Trijuni, Eko

(2020).

https://www.foreximf.com/blog/cara-analisafundamental diakses pada tanggal 2 juni 2020.

Wicaksono, M Yusuf (2016). Pengaruh Inflasi, Kurs Dollar, dan Suku Bunga terhadap Harga Emas di Indonesia.Jurnal Pendidikan dan Ekonomi, Volume 5, Nomor 2, Tahun 2019.

Zhou, Y., Han, L., \& Yin, L. (2018). Is the relationship between gold and the US dollar always negative? The role of macroeconomic uncertainty. Applied Economics, 50(4), 354-370. 